\title{
Genotoxic effects in peripheral blood and urine of workers exposed to low level benzene
}

\author{
A YARDLEY-JONES, ${ }^{1}$ DIANA ANDERSON, ${ }^{2}$ P C JENKINSON, ${ }^{2}$ D P LOVELL, ${ }^{2}$ \\ S D BLOWERS, ${ }^{2} M$ J DAVIES ${ }^{2}$
}

From the Occupational Health Division, ${ }^{1}$ Shell-Mex House, London, and the British Industrial Biological Research Association, ${ }^{2}$ Carshalton, Surrey SM5 4DS, UK

ABSTRACT Blood samples were obtained from a population of refinery workers representing different age groups. Sixty six men with low average exposure to benzene and 33 male controls were investigated. An examination of cell cycle kinetics and sister chromatid exchange was carried out on control and exposed individuals. No significant differences were found between groups of individuals varying in their drinking and smoking habits or their exposure to diagnostic $x$ rays. Individuals with the lowest and highest phenol values were examined for urine mutagenicity, with urinary phenol used here as an indicator of benzene exposure. There was no difference in the number of revertant colonies in strains TA98 and 100 between the high and low urinary phenol groups. There were also no differences in any of the biochemical measures or haematological parameters investigated in all the individuals except that higher values for mean corpuscular volume were found in exposed than in control individuals. These values, however, were within the normal clinical range.

The consequences of exposure to low levels of benzene at or below the current TLV (10 ppm time weighted average (TWA) ) remains controversial and has been the subject of many epidemiology, cancer, and cytogenetic studies. ${ }^{1-4}$ Furthermore, the mechanism by which benzene exerts its toxicity on the haemopoietic system continues to be the subject of research and speculation and has recently been reviewed by Irons $^{5}$ and Latriano et $a l^{6}$, the latter suggesting the important role of a minor pathway in the toxic effects.

Many studies have used the technique of sister chromatid exchange (SCE), which is known to be a sensitive index of genotoxic damage from xenobiotics, to show the effect of benzene at various dose levels. Erexson et al exposed human lymphocytes to a number of known and suspected benzene metabolites in vitro and found dose dependent increases in SCE, decreases in mitotic indices, and inhibition of cell cycle kinetics. ${ }^{7}$ In addition they showed increases in SCE in blood lymphocytes of mice after inhalation studies at 10,100 , and $1000 \mathrm{ppm}$ benzene for six hours. ${ }^{8}$ Studies by Tice $e t$ al also showed increases in SCE frequency in

Accepted 12 October 1987 mice after exposure to benzene. 9 Styles and Richardson showed dose related increases in SCE in rats at levels of $1,10,100,1000 \mathrm{ppm}$ after a six hour exposure regimen. ${ }^{10}$

Watanabe et al were unable to show any increase in SCE in the peripheral lymphocytes of workers exposed to a maximum of $40 \mathrm{ppm}$ for between one and 20 years." Sarto et al examined peripheral blood lymphocytes from 22 individuals. ${ }^{12}$ Exposures ranged from $0 \cdot 2-12.4 \mathrm{ppm}$ TWA but were probably higher some years previously. Other possible confounding variables were taken into consideration. No significant increase in SCE was observed between the exposed group and paired controls, but a comparison of the high and low exposure groups suggested a correlation between the levels of exposure to benzene and the presence of SCE, confirming similar observations made by. Watanabe et al. ${ }^{11}$ Clare et al in the study of 10 workers after a single acute high exposure to benzene found a non-significant increase in SCE values, although the study was conducted three months after the incident and the numbers were small. ${ }^{13}$

As part of a larger study, the present communication investigates the incidence of SCE, cell cycle kinetics, and urine mutagenicity in a group of workers occupationally exposed to low levels of benzene. 
Table 1 Classification of exposure of operators and maintenance personnel in different working areas

\begin{tabular}{|c|c|c|c|c|c|c|c|c|c|}
\hline \multirow[b]{3}{*}{ Process } & \multirow[b]{3}{*}{ Job type } & \multirow{3}{*}{$\begin{array}{l}\text { No } \\
\text { in job }\end{array}$} & \multicolumn{2}{|c|}{$\begin{array}{l}\text { Exposure } \\
\text { TWA long term }\end{array}$} & \multicolumn{2}{|c|}{$\begin{array}{l}\text { Exposure } \\
\text { TWA sometime }\end{array}$} & \multicolumn{2}{|c|}{$\begin{array}{l}\text { Level } \\
\text { sometime }\end{array}$} & \multirow[b]{3}{*}{ Material } \\
\hline & & & (ppm) & $(p p m)$ & (ppm) & (ppm) & (ppm) & $(p p m)$ & \\
\hline & & & $1-5$ & $<1$ & $5-10$ & $1-5$ & $>100$ & $10-100$ & \\
\hline Shipping & Operators & 16 & 2 & 14 & 16 & & 16 & & Pygas \\
\hline $\begin{array}{l}\text { Oil movements } \\
\text { Shipping }\end{array}$ & Operators & 50 & & 50 & & 50 & & 50 & Mogas \\
\hline $\begin{array}{l}\text { oil movements } \\
\text { Aromatics } \\
\text { Aromatics }\end{array}$ & $\begin{array}{l}\text { Maintenance } \\
\text { Operators } \\
\text { Maintenance }\end{array}$ & $\begin{array}{l}25 \\
28 \\
40\end{array}$ & $\begin{array}{l}3 \\
4\end{array}$ & $\begin{array}{l}22 \\
28 \\
36\end{array}$ & $\begin{array}{l}25 \\
40\end{array}$ & 28 & $\begin{array}{l}25 \\
28 \\
40\end{array}$ & & $\begin{array}{l}\text { Mogas } \\
\text { Benzene } \\
\text { Benzene } \\
\text { stream }\end{array}$ \\
\hline
\end{tabular}

Pygas: about $30 \%$ benzene. Mogas: about $1 \cdot 5 \%$ benzene. Benzene stream: $30-100 \%$ benzene.

\section{Materials and methods}

\section{WORKERS ANALYSED}

Blood samples were obtained from workers representing different age groups within a refinery population. Sixty six men with low average exposure to benzene and 33 male controls were investigated. The 66 men worked in jobs where benzene or material containing benzene was handled and all had been potentially exposed to benzene for periods in excess of five years. Three main work areas were identified: shipping, oil movements, and aromatics production. Exposures in the present study were assumed to be of the same order as those of previous personal and workplace air samples taken from individuals in similar jobs collected over a period of years. The latter data are classified in table 1 , according to shift average (TWA) and level (time unspecified). The controls were selected from the refinery population based on evidence of presumed non-exposure to known genotoxic agents. A detailed questionnaire on health status and social habits was compiled for each individual. The blood samples were collected at weekly intervals in batches of eight over 13 weeks. Table 2 shows the numbers of individuals categorised by age, tobacco smoking, and alcohol consumption.

\section{HAEMATOLOGY AND BIOCHEMISTRY PROFILES}

The haematology values, including mean corpuscular volume and haemoglobin, were obtained using a Coulter counter Z56 system. Serum biochemistry values were obtained using standard Boehringer reagents on a Hitachi 705 .

\section{URINARY PHENOL}

Urine samples were collected early in the morning. The urine was processed as described elsewhere ${ }^{14}$ and analysed by GLC and flame ionisation (Hewlett Packard GLC 5703A). The results were then standardised to a urine specific gravity of 1024 .

\section{SAMPLE COLLECTION AND CELL GROWTH}

Blood was collected by venepuncture during the early morning. Haematology smears were prepared

Table 2 Individuals categorised by age, exposure, smoking, and drinking habits

\begin{tabular}{|c|c|c|c|c|c|c|c|c|c|c|c|c|c|c|c|c|c|c|}
\hline \multirow{3}{*}{$\begin{array}{l}\text { Drinking, } \\
\text { smoking: }\end{array}$} & \multicolumn{18}{|c|}{ Age interval (years) } \\
\hline & \multicolumn{3}{|c|}{$(20-24)$} & \multicolumn{3}{|c|}{$(25-34)$} & \multicolumn{3}{|c|}{$(35-44)$} & \multicolumn{3}{|c|}{$(45-54)$} & \multicolumn{3}{|c|}{$(55-60)$} & \multicolumn{3}{|c|}{ (All) } \\
\hline & $\overline{-}$ & + & ++ & $\overline{-}$ & + & ++ & $\overline{-}$ & + & ++ & $\overline{-}$ & + & ++ & $\overline{-}$ & + & ++ & $\overline{-}$ & + & ++ \\
\hline $\begin{array}{l}\text { Exposed group: } \\
\text { Non } \\
\text { Ex } \\
\text { Current } \\
\text { Control group: }\end{array}$ & $\begin{array}{l}1 \\
0 \\
0\end{array}$ & $\begin{array}{l}0 \\
0 \\
0\end{array}$ & $\begin{array}{l}0 \\
0 \\
0\end{array}$ & $\begin{array}{l}0 \\
0 \\
2\end{array}$ & $\begin{array}{l}2 \\
0 \\
0\end{array}$ & $\begin{array}{l}0 \\
1 \\
4\end{array}$ & $\begin{array}{l}1 \\
2 \\
0\end{array}$ & $\begin{array}{l}5 \\
7 \\
6\end{array}$ & $\begin{array}{l}1 \\
5 \\
4\end{array}$ & $\begin{array}{l}1 \\
0 \\
3\end{array}$ & $\begin{array}{l}2 \\
2 \\
5\end{array}$ & $\begin{array}{l}0 \\
4 \\
2\end{array}$ & $\begin{array}{l}1 \\
1 \\
1\end{array}$ & $\begin{array}{l}0 \\
1 \\
1\end{array}$ & $\begin{array}{l}0 \\
0 \\
1\end{array}$ & $\begin{array}{l}4 \\
3 \\
6\end{array}$ & $\begin{array}{r}9 \\
10 \\
12\end{array}$ & $\begin{array}{r}1 \\
10 \\
11\end{array}$ \\
\hline $\begin{array}{l}\text { Non } \\
\text { Ex } \\
\text { Current }\end{array}$ & $\begin{array}{l}1 \\
0 \\
0\end{array}$ & $\begin{array}{l}1 \\
1 \\
0\end{array}$ & $\begin{array}{l}0 \\
0 \\
0\end{array}$ & $\begin{array}{l}0 \\
0 \\
0\end{array}$ & $\begin{array}{l}5 \\
4 \\
1\end{array}$ & $\begin{array}{l}0 \\
0 \\
4\end{array}$ & $\begin{array}{l}1 \\
0 \\
0\end{array}$ & $\begin{array}{l}0 \\
2 \\
0\end{array}$ & $\begin{array}{l}1 \\
2 \\
0\end{array}$ & $\begin{array}{l}0 \\
0 \\
1\end{array}$ & $\begin{array}{l}1 \\
1 \\
3\end{array}$ & $\begin{array}{l}0 \\
0 \\
2\end{array}$ & $\begin{array}{l}0 \\
0 \\
1\end{array}$ & $\begin{array}{l}0 \\
1 \\
0\end{array}$ & $\begin{array}{l}0 \\
0 \\
0\end{array}$ & $\begin{array}{l}2 \\
0 \\
2\end{array}$ & $\begin{array}{l}7 \\
9 \\
4\end{array}$ & $\begin{array}{l}1 \\
2 \\
6\end{array}$ \\
\hline $\begin{array}{l}\text { All: } \\
\text { Non } \\
\text { Ex } \\
\text { Current }\end{array}$ & $\begin{array}{l}2 \\
0 \\
0\end{array}$ & $\begin{array}{l}1 \\
1 \\
0\end{array}$ & $\begin{array}{l}0 \\
0 \\
0\end{array}$ & $\begin{array}{l}0 \\
0 \\
2\end{array}$ & $\begin{array}{l}7 \\
4 \\
1\end{array}$ & $\begin{array}{l}0 \\
1 \\
8\end{array}$ & $\begin{array}{l}2 \\
2 \\
0\end{array}$ & $\begin{array}{l}5 \\
9 \\
6\end{array}$ & $\begin{array}{l}2 \\
7 \\
4\end{array}$ & $\begin{array}{l}1 \\
0 \\
4\end{array}$ & $\begin{array}{l}3 \\
3 \\
8\end{array}$ & $\begin{array}{l}0 \\
4 \\
4\end{array}$ & $\begin{array}{l}1 \\
1 \\
2\end{array}$ & $\begin{array}{l}0 \\
2 \\
1\end{array}$ & $\begin{array}{l}0 \\
0 \\
1\end{array}$ & $\begin{array}{l}6 \\
3 \\
8\end{array}$ & $\begin{array}{l}16 \\
19 \\
16\end{array}$ & $\begin{array}{r}2 \\
12 \\
17\end{array}$ \\
\hline
\end{tabular}

Non-smoker, smoked only occasionally; ex-smoker, stopped three or more months ago; current smoker, one or more cigarettes, cigars, or pipes a day.

Drinking: $<2$ units/week $(-), 2-20$ units/week $(+),>20$ units/week $(++)$. 
immediately. Blood for cell counts was placed in $1 \mathrm{ml}$ sequestrene tubes. Blood for lymphocyte culture was heparinised with $50 \mathrm{IU} \mathrm{ml} \mathrm{sodium} \mathrm{heparin} \mathrm{and} \mathrm{kept} \mathrm{at}$ room temperature.

The next morning, duplicate, $0.8 \mathrm{ml}$ volumes of blood were washed in $10 \mathrm{ml}$ of Eagle's minimal essential medium (Gibco). Centrifuged cell pellets, about $0.5 \mathrm{ml}$, were suspended in $9.5 \mathrm{ml}$ of medium supplemented with $50 \mathrm{IU}$ penicillin and $50 \mu \mathrm{g}$ streptomycin per $\mathrm{ml}$ (Gibco) and $15 \% \mathrm{v} / \mathrm{v}$ heat inactivated fetal calf serum (Sera Lab, Crawley, Sussex). A $0 \cdot 1 \mathrm{ml}$ volume of reconstituted reagent grade phytohaemagglutinin (PHA-R, Wellcome) and $0.05 \mathrm{ml}$ of $5 \mathrm{mM}$ bromodeoxyuridine (Sigma) to give $25 \mu \mathrm{M}$ were added per culture. All reagents used were from the same batches purchased before the start of the study except that at week 5 a new solution of the same batch of bromodeoxyuridine was prepared.

HAR VESTING AND SLIDE PREPARATION

At 70 hours, $0.05 \mathrm{ml}$ of $10 \mu \mathrm{g}$ per $\mathrm{ml}$ demecolcine (Sigma) was added per culture. After a further two hours incubation cells were harvested by centrifugation, swollen in $0.075 \mathrm{M} \mathrm{KCl}$, and fixed in repeated changes of $3: 1$ methanol, acetic acid.

Slides were stained using a modified form of the original FPG technique. ${ }^{15}$

SISTER CHROMATID EXCHANGE AND CELL CYCLE KINETIC SCORING

Slides were scored under a random number code. Twenty five cells were scored per culture, with a maximum of 13 cells from any one slide. Only diploid second metaphase (M2) cells with between 45 and 47 centromeres were scored. Every point of exchange was counted as an SCE. Exchanges at the centromere were included only when twisting at this point could be ruled out.

Cell cycle kinetics were measured by calculating the proliferative rate index (PRI) for each slide. This was accomplished by measuring the number of different metaphase divisions observed on slides prepared for SCE studies. The PRI was calculated by $(1 \times M 1+$ $2 \times \mathrm{M} 2+3 \times \mathrm{M} 3) / 100$ where M1, M2, and M3 were the number of cells in first, second, and third metaphase based on their differential staining with bromodeoxyuridine. High values of PRI are indicative of a high rate of proliferation.

\section{AMES TEST ON URINE SAMPLES}

Urine was collected in the early morning from the individuals and stored at $-20^{\circ} \mathrm{C}$ initially. The urine samples were thawed at room temperature and centrifuged at $1000 \mathrm{~g}$ for 10 minutes to remove debris. The resultant supernatants were sterilised by filtration through a 0.45 micro m "Acrodisc" (Gelman Science).
The samples were then incubated for 24 hours at $37^{\circ} \mathrm{C}$, with 65 units/ml of Beta-glucuronidase/sulphatase solution (Sigma) before use in the Ames test. Aliquots $(0.5 \mathrm{ml})$ of the processed urines were incorporated, in triplicate, in the standard plate incorporation test as described by Maron and Ames in the presence of a $10 \%$ S9 mix. ${ }^{16}$ The Salmonella typhimurium strains TA98 and TA100 were obtained from Professor B N Ames, University of California, USA.

Unless otherwise indicated the media and chemicals used were from standard sources as described elsewhere. $^{16}$

\section{STATISTICAL ANALYSIS}

Data were analysed by factorial analysis of variance. Investigations of variability between individuals and the relation with sex, age, and lifestyle factors were carried out using stepwise multiple linear regression. Statistical analyses were carried out using the Genstat and Minitab statistical packages. The Ames test data were analysed by a $2 \times 2$ analysis of variance to investigate the effect of the different variables of the mean number of revertants per plate per individual in the four groups of both strains. Since different solutions of bromodeoxyuridine were used in weeks 1-4 and 5-13, values obtained for PRI and SCE were also analysed using Student's $t$ test on mean values for exposed and controls in these two sets of batches.

\section{Results}

PROLIFERATIVE RATE INDEX

Analyses were carried out on the satisfactory preparations of PRI from 80 individuals. No values were obtained for 19 subjects. No significant differences were found in the analysis of variance between groups of individuals differing in their drinking, smoking habits or their exposure to diagnostic $x$ rays. There was, however, a significant difference in PRI between the 31 control and 49 exposed individuals $(1.90 v 1.74$; $p<0.01)$ when all 13 batches of individuals were analysed. Significant $(p<0.001)$ differences were also seen in the mean PRI values between the two sets of batches with mean PRI values ranging from 1.38 to 1.85 in batches $1-4$ and 1.51 to 2.19 in batches $5-13$. There was no significant difference, however, between exposed and control individuals within the two sets of batches.

Stepwise multiple linear regression analysis suggested that there was a slight effect of age on PRI (with a decrease in the PRI score of 0.0075 with each increasing year of age).

\section{HAEMATOLOGY}

No differences were detected in any of the biochemical parameters investigated. This was also the case for the 


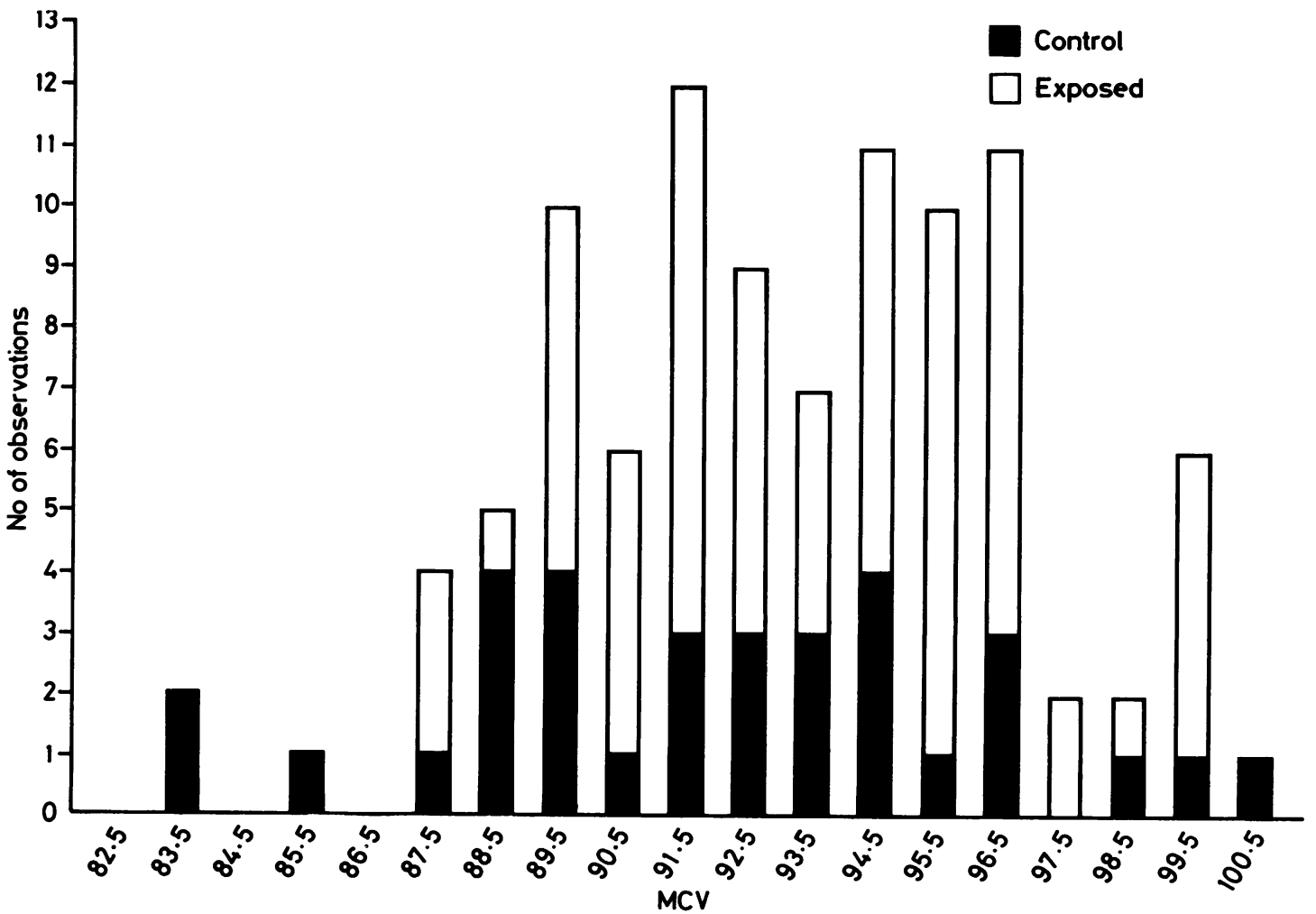

Fig 1 Mean corpuscular volume values in control and exposed individuals.

haematology values, with one exception, where an analysis of variance gave a significant result: the exposed individuals had increased MCVs compared with the control subjects ( $93.1 v 91.5 ; \mathrm{p}<0.05)$. This distribution may be seen in fig 1 where the values of control individuals ranged from 83 to 100 whereas the values of exposed individuals ranged from 87 to 99 . No variability was detected between the batches or for any other factor.

Table 3 Mean revertants in different groups in Salmonella typhimurium TA98

\begin{tabular}{lll}
\hline & $\begin{array}{l}\text { Smoking } \\
(n=7)\end{array}$ & $\begin{array}{l}\text { Non-smoking } \\
(n=9)\end{array}$ \\
\hline High phenol & $91 \cdot 2\left(\mathrm{X}_{1}\right)$ & $57 \cdot 6\left(\mathrm{X}_{2}\right)$ \\
& $(n=7)$ & $\begin{array}{l}(n=9) \\
58 \cdot 3\left(\mathrm{X}_{4}\right)\end{array}$ \\
\hline
\end{tabular}

$2 \times 2$ Factorial analysis and variance.

(i) Effect of smoking $X_{1}+X_{3}=X_{2}+X_{4}$ giving $p<0.05$.

(ii) Effect of phenol exposure $X_{1}+X_{2}=X_{3}+X_{4}$ not significant.

(iii) Effect of phenol/smoking interactions, $X_{1}+X_{4}=X_{2}+X_{3}$ not significant.

(iv) Variation between individuals $\mathrm{p}<0.001$.
AMES TEST DATA

Since in this study urinary phenol is used as an indicator of exposure to benzene, individuals were selected and grouped into low and high phenol values. Those with the lowest and highest phenol values were investigated (ranges $1-7,12-54 \mathrm{mg} / 1$ respectively). Individuals were also matched for smoking and nonsmoking, age, and, where possible, alcohol intake. The Ames test data are presented in tables 3 and 4 as mean

Table 4 Mean revertants in different groups in Salmonella typhimurium TA100

\begin{tabular}{lll}
\hline & $\begin{array}{l}\text { Smoking } \\
(n=7)\end{array}$ & $\begin{array}{l}\text { Non-smoking } \\
(n=9)\end{array}$ \\
\hline High phenol & $188.6\left(\mathrm{X}_{1}\right)$ & $141.6\left(\mathrm{X}_{2}\right)$ \\
Low phenol & $\begin{array}{l}(n=7) \\
168 \cdot 5\left(\mathrm{X}_{3}\right)\end{array}$ & $\begin{array}{l}(n=9) \\
162.8\left(\mathrm{X}_{4}\right)\end{array}$ \\
\hline
\end{tabular}

$2 \times 2$ Factorial analysis and variance

(i) Effect of smoking $X_{1}+X_{3}=X_{2}+X_{4}$ not significant.

(ii) Effect of phenol exposure $X_{1}+X_{2}=X_{3}+X_{4}$ not significant.

(iii) Effect of phenol/smoking interactions, $X_{1}+X_{4}=X_{2}+X_{3}$ not significant.

(iv) Variation between individuals $\mathrm{p}<0.001$. 


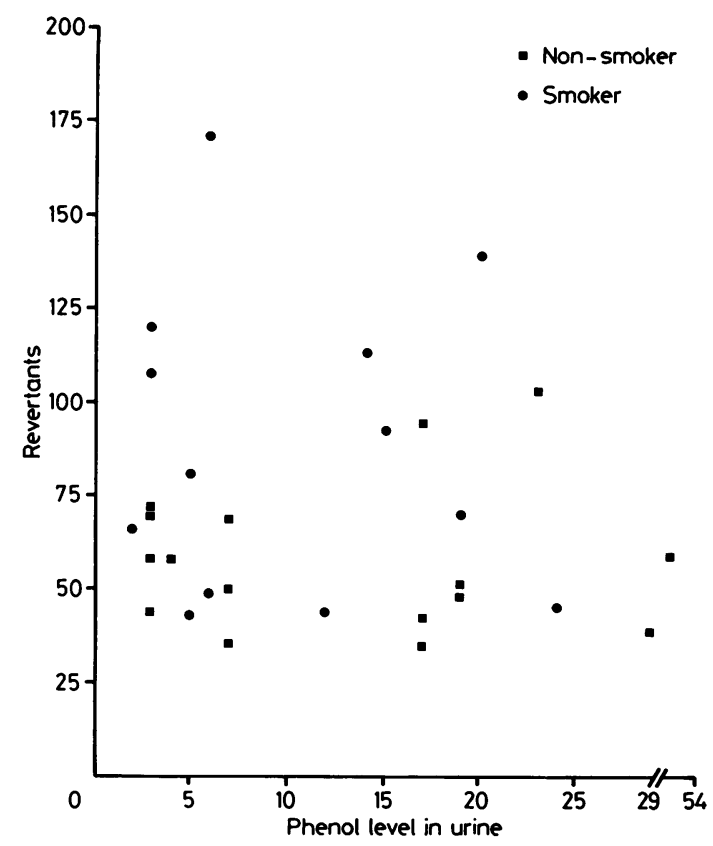

Fig 2 Mean revertants in non-smoking and smoking individuals against urinary phenol values in $\mathrm{mgs} / \mathrm{l}$.

revertants for the various subgroups. There was no difference between the high urinary phenol group and the low urinary phenol group. In strain TA98, however, there was a significant increase in revertants in smokers, by comparison with non-smokers $(p<0.05)$. The biggest source of variation in revertants was between individuals in both strains, $(p<0.001)$, whereas the variability among triplicate plates was relatively small and insignificant. In strain TA98 there was no correlation between phenol values and revertants in smoking and non-smoking individuals (fig 2), although there was a suggestion of a positive correlation between revertants and the age of the individual (fig 3 ).

\section{SISTER CHROMATID EXCHANGE}

Fifty one preparations were suitable for SCE analysis ( 23 control, 28 exposed individuals). Of these, 36 had duplicate cultures available. A hierarchial analysis of variance showed both significant variation between these 36 individuals and between the duplicate cultures (both $\mathrm{p}<0.001$ ). Most of the variation in the data, however, was between cells ( $82 \%$ ) compared with $14 \%$ between individuals and $4 \%$ between cultures. The between culture variability could be traced to six individuals where there were significant differences between the two replicate cultures as measured by pooled two sample $t$ tests. There was no significant difference between the control and exposed
Yardley-Jones, Anderson, Jenkinson, Lovell, Blowers, Davies individuals (fig 4) (exposed $\mathrm{n}=28$, mean $\pm \mathrm{SD}: 9.44 \pm 2.00 ;$ control $\mathrm{n}=23$, mean \pm SD : $8.95 \pm 1.62$ ). Despite the large variation between batches 1-4 and 5-13 (fig 5), the difference between control and exposed individuals within batches was small. The variability within groups provides an estimate of the power of the study to detect possible differences between two groups. Sample sizes of about 60 would be necessary for a $90 \%$ chance of detecting a difference of one SCE between two groups at the 5\% significance level. Sample sizes of about 15 would be needed to detect a 2 SCE difference under the same assumption.

\section{Discussion}

Various parameters have been investigated in exposed and control workers in the present study. The study was controlled in that all reagents for genotoxic and kinetic analysis were purchased as one batch before the start of the study. A new solution of bromodeoxyuridine was prepared for SCE and PRI determination at week 5. Probably the apparent variation in PRI in control and exposed individuals is an artefact of the distribution of the individuals into different batches. This is supported by the observation that there are no differences in mean PRI values of the two sets of batches of individuals resulting from the week 5 bromodeoxyuridine solution change. Records indicate, however, that bromodeoxyuridine solutions were both made up correctly and some other unknown factor may be responsible for differences in batches of

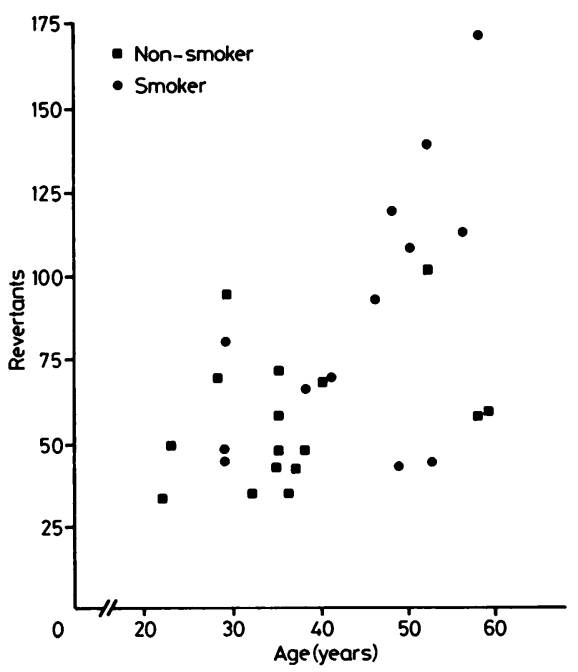

Fig 3 Mean revertants in smoking and non-smoking against age in years. 


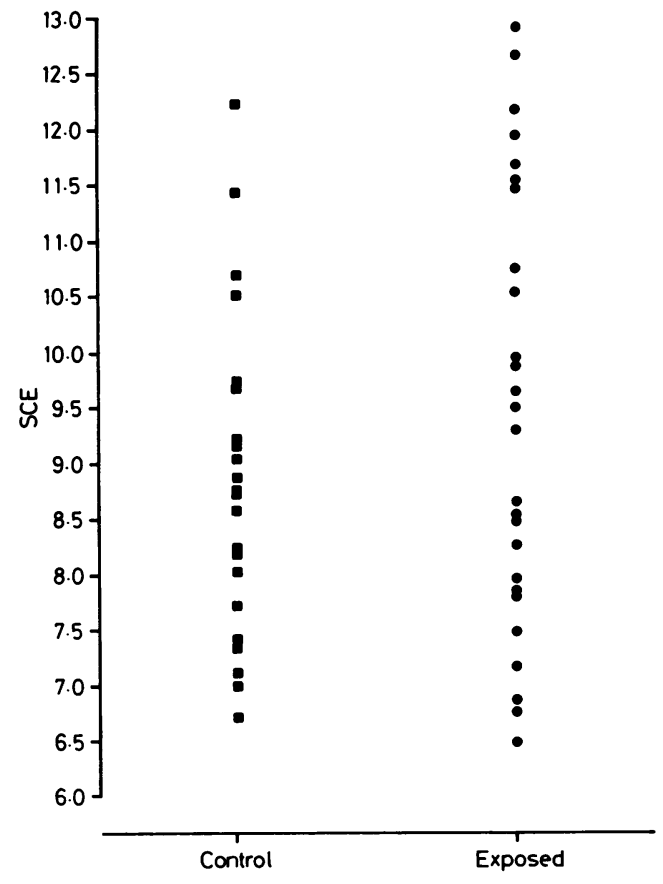

Fig 4 Mean sister chromatid exchange per metaphase in control and exposed individuals.

individuals, such as seasonal variation. The decrease of PRI with age is consistent with observations that mitogen induced blastogenesis also decreases with age $^{17}$ (and Yardley-Jones et al, unpublished data).

Despite batch variability, there was no difference in SCE between exposed and controls. A similar observation was made by Zhou et al for petrochemical workers. ${ }^{18}$ For the PRI data, there were unfortunately fewer controls to analyse by comparison with exposed values in batches 1-4 and this excess of low values of PRI in exposed workers could bias the data. For SCE in batches $1-4$, of those samples that were analysable, control and exposed were more evenly distributed. It would appear that there are no real differences between exposed and control workers either for PRI or SCE values.

The haematological and biochemical parameters showed no differences between exposed and control groups. The statistical analysis of the mean corpuscular volume data, however, showed a small but significant difference between the exposed and control groups. Although differences in mean corpuscular volume have been described as an indication of marrow toxicity in alcohol and benzene poisoning, ${ }^{19-21}$ the absolute values observed in the present study are within the normal clinical range (76-96 fL).

The Ames test data on selected samples showed no

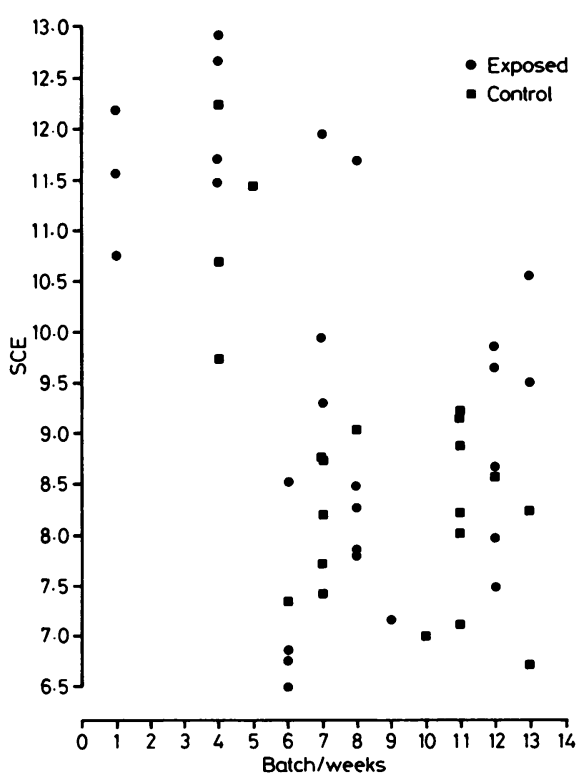

Fig 5 Mean sister chromatid exchange in exposed and control against batch numbers in weeks.

differences in the mutagenicity of the urine samples from high and low phenol groups. There was a significant difference, however, in revertants induced in strain TA98 for samples from smokers by comparison with non-smokers; this has previously been described in strain TA98 and not in TA100. ${ }^{22}$ There was also an increase in revertants with age in smokers and non-smokers in both groups in strain TA98, which is an interesting observation. No correlation was found between urinary phenol and revertants in either strain. This is not surprising, however, owing to the relatively low levels of phenol in urine which are assumed to result from low exposure to benzene.

In conclusion, the study would suggest that at the levels of exposure of benzene experienced by the workforce at the time of, and a short time before, the study there were no effects on haematological/ biochemical parameters, PRI, SCE, and urine mutagenicity.

We thank the employees who took part in the study and Professor D H Elliott and Dr A C MacLean for their early support; $\mathrm{Mr}$ I Smith for the preparation of the blood samples; Dr R C Dewdney, Mrs S K Doubell, and Mrs L Smith for help in the processing and analyses of the samples; and Dr M K Molyneux for the exposure data.

Requests for reprints to Dr A Yardley-Jones, BIBRA, Carshalton, Surrey SM5 4DS. 


\section{References}

1 International Agency for Research on Cancer. IARC Monographs Eval Carcinog Risk Chem Hum 1982;4 (suppl):56-7.

2 Vigliani EC. Leukaemia associated with benzene exposure. Ann NY Acad Sci 1976;271:134-51.

3 Maltoni C, Conti B, Cotti G. Benzene: a multipotential carcinogen. Results of long-term bioassays performed at the Bologna Institute of Oncology. Am J Ind Med 1983;4:589-630.

4 Dean BJ. Recent findings on the genetic toxicology of benzene, toluene, xylenes and plenols. Mutat Res 1985;154:153-81.

5 Irons RD. Quinones as toxic metabolites of benzene. $J$ Toxicol Environ Health 1985;16:673-8.

6 Latriano L, Goldstein BD, Witz G. Formation of muconaldehyde, an open-ring metabolite of benzene, in mouse liver microsomes: an additional pathway for toxic metabolites. Proc Natl Acad Sci USA 1986;83:8356-60.

7 Erexson GL, Wilmer JL, Auman CD, Kligerman AD. Induction of sister chromatid exchange and micronuclei in male DBA/2 mice after inhalation of benzene. Environ Mutagen 1984;6:408.

8 Erexson GL, Wilmer JL, Kligerman AD. Sister chromatid exchange induction in human lymphocytes exposed to benzene and its metabolites in vitro. Cancer Res 1985;45:2471-7.

9 Tice RR, Costa DL, Drew RT. Cytogenetic effects of benzene in murine bone marrow. Induction of sister chromatid exchanges, chromosomal abberrations and cellular proliferation inhibition in DBA/2 mice. Proc Natl Acad Sci USA 1980;4:2148-52.

10 Styles JA, Richardson CR. Cytogenetic effects of benzene: dosimetric studies on rats exposed to benzene vapour. Mutat Res 1984;135:203-9.

11 Watanabe T, Endo A, Kato Y, Shima S, Watanabe T, Ikeda M. Cytogenetics and cytokinetics of cultured lymphocytes from benzene-exposed workers. Ind Arch Occup Environ Health 1980;46:31-41.

12 Sarto F, Cominato I, Pinton AM, et al. A cytogenetic study on workers exposed to low concentrations of benzene. Carcinogenesis 1984;5:827-32.

13 Clare MG, Yardley-Jones A, McLean AC, Dean BJ. Chromosome analysis from peripheral blood lymphocytes of workers after acute exposure to benzene. Br J Ind Med 1984;41:249-53.

14 Baldwin MK, Selby MA, Bloomberg $H$. Measurement of phenol in urine by the method of Van Haaften and Sie: a critical appraisal. Analyst 1981;106:763-7.

15 Perry P, Wolff S. New Glemsa method for the differential staining of sister chromatids. Nature 1974;251:156-8.

16 Maron DM, Ames BN. Revised methods for the salmonella mutagenicity tests. Mutat Res 1983;113:173-215.

17 Campbell MJ, Wagner MMF, Scott MP, Brown DG. Sequential immunological studies in an asbestos-exposed population. Clin Exp Immunol 1980;39:176-82.

18 Zhou X, Li L, Cui M, Yu R, Li L, Yan Z. Cytogenetic monitoring of petrochemical workers. Mutat Res 1986;175:237-42.

19 Aksoy M, Dincol K, Akgun T. Haematological effects of chronic benzene poisoning in 217 workers. Br J Ind Med 1971;28: 296-302.

20 Hutchings M, Drescher S, McGovern FB. Investigation of benzol and toluol poisoning in Royal Australian Air Force work shops. Med J Aust 1947;2:681-93.

21 Unger KW, Johnson D Jr. Red blood cell mean corpuscular volume: a potential indicator of alcohol usage in a working population. Am J Med Sci 1974;267:281-9.

22 Yamasaki E, Ames BN. Concentration of mutagens from urine by absorption with the non-polar resin XAD-2: cigarette smokers have mutagenic urine. Proc Natl Acad Sci USA 1977;74:3555-9. 